\title{
EKSPRESI mRNA INTERLEUKIN-10 (IL-10) DALAM KAITANNYA DENGAN PATOGENESIS MALARIA BERAT PADA MENCIT STRAIN BALB/C YANG DIINFEKSI PLASMODIUM YOELII 17XL
}

\author{
Sri Wijayanti Sulistyawati ${ }^{1,2,3}$, Sukmawati Basuki ${ }^{1,2}$, Yoes Prijatna Dachlan ${ }^{1,2}$ \\ 1 Departemen Parasitologi Kedokteran, Fakultas Kedokteran Universitas Airlangga, Surabaya \\ 2 Kelompok Studi Malaria, Lembaga Penyakit Tropis Universitas Airlangga, Surabaya \\ 3Program Studi S2 Imunologi, Universitas Airlangga, Surabaya \\ e-mail: *yanti.parasito@gmail.com, sukmabas@yahoo.com, yoesdachlan.rspti@gmail.com
}

\begin{abstract}
Abstrak
Patogenesis malaria berat masih belum diketahui menyeluruh. Episode malaria berat dapat disebabkan oleh dua keadaan, produksi tinggi pada fase awal IL-10 dan atau kurangnya produksi IL-10 pada fase transisi. Peran IL-10 pada malaria masih belum jelas diketahui. Penelitian ini bertujuan untuk menganalisis ekspresi IL-10 dalam kaitannya dengan patogenesis malaria berat pada mencit strain BALB/c yang diinfeksi P. yoelii 17XL.

Penelitian eksperimental laboratoris dengan rancangan "post test only control group design" dilakukan, dan menggunakan 24 mencit strain BALB/c, betina, usia 7-8 minggu, yang dibagi menjadi 4 kelompok. Mencit BALB/c diinfeksi secara intraperitoneal dengan $1 \times 10^{5} \underline{\text { P. yoelii } 17 X L}$, dan dikorbankan pada hari ke-3 dan ke-6 pasca infeksi. Parasitemia dan kadar hemoglobin diperiksa setiap hari. Jaringan limpa

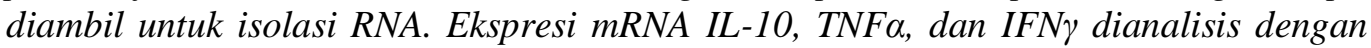
$R T-P C R$.

Mencit BALB/c dinfeksi dengan $1 \times 10^{5}$ P. yoelii $17 X L$ menunjukan infeksi letal, yang ditandai dengan peningkatan parasitemia sejalan dengan penurunan kadar hemoglobin, terjadi setelah hari ke-3 pasca infeksi. Ekspresi mRNA IL-10, begitu pula dengan TNFa dan IFNy pada hari ke-3 paska infeksi menunjukan peningkatan dibandingkan pada kontrol dan hari ke-6 paska infeksi.

Tidak adanya ekspresi IL-10 pada H6, menunjukkan kemungkinan adanya kegagalan regulator mengontrol malaria berat pada infeksi P. yoelii 17XL pada mencit $B A L B / c$.
\end{abstract}

Kata kunci- mRNA IL-10, RT-PCR, patogenesis malaria berat, mencit BALB/c yang diinfeksi P. yoelii 17XL 


\begin{abstract}
The pathogenesis of severe malaria is still unsolved. The role of IL-10 in the pathogenesis of malaria still unclear. This study was aimed to analyze mRNA expression of IL-10 on the pathogenesis of severe malaria in strain BALB/c mice infected with P. yoelii 17XL.

The laboratory experimental research with post test only-control group design was conducted. A total of $24 \mathrm{BALB/c}$ mice, female, age 7-8 weeks, were divided into 4 groups. $B A L B / c$ mice were infected intraperitoneally with $1 \times 10^{5} \mathrm{P}$. yoelii $17 \mathrm{XL}$, and were sacrificed on Day-3 and Day-6 post infection. Parasite count and hemoglobin level were observed daily.

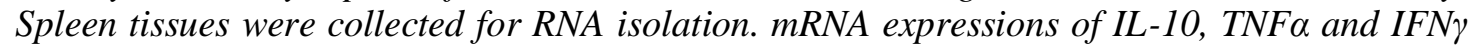
were analysed by $R T-P C R$ technique.

$B A L B / c$ mice infected with $P$. yoelii $17 X L$ caused lethal infection with signs of increasing parasitemia synchronize with the decreasing levels of hemoglobin after the day-3 postinfection. Expression of mRNA of IL-10, TNFa, and IFN were increased on the day 3 post infection, compared with day 0 and day 6 post infection.

This study suggested that the absent of mRNA expression of IL-10 on day 6 may indicate the failure of regulator in controlling severe malaria in P. yoelii $17 X \mathrm{~L}$ infection on BALB/c mice.
\end{abstract}

Keywords - mRNA IL-10, RT-PCR, pathogenesis of severe malaria, BALB/c mice infected by P. yoelii $17 X L$ 


\section{PENDAHULUAN}

Malaria merupakan penyakit parasit yang terpenting. Pada tahun 2010, terdapat 216 juta kasus malaria dan sedikitnya 655 ribu kematian di dunia, terutama pada anak-anak yang tinggal di Afrika (WHO, 2010). Sampai saat ini, di Indonesia malaria masih menjadi masalah kesehatan. Pada tahun 2009 di Indonesia terdapat 544.470 kasus yang dilaporkan, dengan tingkat kematian sebesar 900 per 100.000 penduduk (WHO-SEARO, 2011).

Fenotip klinis infeksi malaria sangat bervariasi (Riley et al, 2006). Keseluruhan pola penyakit dipengaruhi secara nyata oleh umur dan reaksi imun yang dialami hospes (Schofield and Grau, 2005). Alasan yang mendasari perbedaan tersebut belum dipahami sepenuhnya (Angulo and Fresno, 2002). Pemahaman mengenai dasar imunologi mengenai imunitas protektif terhadap malaria dibutuhkan seiring dengan peningkatan multi resistensi terhadap anti malaria disertai resistensi vektor terhadap insektisida yang ada (Hassan et al, 2010; Niikura et al,2011).

Sebagian besar patologi infeksi malaria disebabkan oleh respon inflamasi yang berlebihan terhadap parasit. Sitokin regulatori interleukin-10 (IL-10) diketahui berperan penting untuk mengontrol inflamasi selama infeksi malaria dan memberikan proteksi terhadap imunopatologi, akan tetapi dapat pula mengurangi efektivitas mekanisme imun lainnya dalam mengeliminasi parasit. Untuk mendisosiasi kedua efek IL-10 tersebut, yang memungkinkan kontrol infeksi dan pencegahan patologi berjalan signifikan, perlu pemahaman yang lebih baik mengenai proses produksi IL-10, waktu produksi, dan sel-sel yang memproduksi (Couper et al, 2008).

Data mengenai IL-10 pada manusia masih kontradiktif. Proporsi IL-10 bertambah dengan usia dan berbanding terbalik dengan kasus malaria berat, dan respon IL-10 terhadap peptida Plasmodium bertahan hingga 3 tahun pada masyarakat dari wilayah dengan intensitas transmisi malaria yang berbeda. Pada area dengan endemisitas rendah respon IFN $\gamma$ menurun sesuai dengan waktu, respon IL-10 sel MN perifer stabil hingga 6 tahun (Freitas do Rosario and Langhorne, 2012). Penelitian Long et al menemukan keterlibatan IL-10 dalam pencegahan keparahan penyakit, juga kemungkinan bahwa polimorfisme IL-10 mempengaruhi derajat keparahan malaria telah diinvestigasi, meskipun masih dipertentangkan (Penman and Gupta, 2008). Kadar IL-10 yang tinggi berhubungan dengan penurunan produksi IFN $\gamma$ yang menyebabkan anemia yang parah pada infeksi Plasmodium falciparum (Niikura et al, 2011). Pada anakanak di Ghana yang menderita malaria falsiparum, kadar IL-10 dalam sirkulasi yang rendah berhubungan dengan anemia malaria yang berat (Wilson et al, 2005). Namun, kadar IL-10 diiringi TNF $\alpha$ yang tinggi juga dilaporkan pada kasus malaria berat dan dengan komplikasi serta pada malaria anak dengan parasitemia yang tinggi (Othoro et al,1999; Keller et al, 2006). Rasio IL-10/TNF yang rendah berhubungan dengan anemia malaria berat (Niikura et al, 2011). Hubungan antara IL-10 dengan sitokin lain penting dalam sistem imun terhadap malaria.

Pada infeksi malaria di mencit, diketahui efek negatif, maupun efek protektif IL-10 terhadap respon inflamasi (Niikura et al, 2011). Sekresi IL-10 pada fase awal infeksi $P$. yoelii berhubungan dengan respon IFN $\gamma$ dan $\mathrm{TNF} \alpha$ yang tumpul dan memanjang (Freitas do Rosario and Langhorne, 2012). Pada mencit dengan IL-10-deficient terjadi supresi peningkatan parasitemia selama koinfeksi parasit letal dan nonletal, namun terjadi kegagalan eliminasi parasit komplit dan menyebabkan kematian (Niikura et al, 2011).

Studi mengenai severe malaria dengan hewan coba penting untuk pemahaman mengenai pathogenesis malaria, khususnya peranan IL-10 pada patogenesis severe malaria, penelitian ini bertujuan untuk mendeteksi ekspresi mRNA IL-10 pada limpa mencit strain BALB/c yang diinfeksi $P$. yoelii $17 X L$ dalam kaitannya dengan patogenesis malaria

berat. 


\section{METODE PENELITIAN}

Jenis penelitian ini adalah penelitian eksperimental laboratoris dengan menggunakan rancangan post test only control group design (Zainuddin, 2000), dan telah layak etik (Keterangan Kelaikan Etik KEPK FKUA No 035/EC/KEPK/FKUA/2012) dan dilakukan di Lembaga Penyakit Tropis (LPT) Universitas Airlangga. Penelitian ini dilakukan selama 2 bulan.

Sampel penelitian adalah mencit strain $\mathrm{BALB} / \mathrm{c}$ sehat, betina dan berusia $7-8$ minggu yang diperoleh dari Laboratorium Penelitian dan Pengujian Terpadu (LPPT) Universitas Gajah Mada (UGM) sebanyak 24 ekor. Mencit dibagi menjadi 4 kelompok yaitu kelompok kontrol (kontrol negatif), kelompok perlakuan (dibagi menjadi dua kelompok, yaitu H3 dan H6), kelompok survival (kontrol positif). Kelompok perlakuan dan kelompok survival merupakan mencit BALB/c yang diinfeksi secara injeksi intraperitoneal sebanyak $1 \times 10^{5} P$. yoelii $17 X L$. Kelompok survival merupakan kelompok perlakuan yang diamati sampai mati.

$P$. yoelii $17 X L$ diperoleh dari Balai Penelitian dan Pengembangan Kesehatan Republik Indonesia, Jakarta. P. yoelii 17XL adalah strain parasit yang hanya menginfeksi mencit. Mencit tersebut akan mengalami malaria berat yang ditandai dengan anemia berat $(\mathrm{Hb}<5 \mathrm{gr} \%)$ dan hiperparasitemia (parasitemia darah tepi> 5\%) (WHO, 2010), berakhir dengan kematian (bersifat letal). Sebelum diinfeksi dilakukan dua kali pasase, kemudian dilakukan infeksi sebanyak $1 \times 10^{5}$ $P$. yoelii $17 X L$ secara intraperitoneal pada setiap mencit. Selanjutnya dilakukan pengukuran kadar hemoglobin $(\mathrm{Hb})$ dan parasitemia setiap hari.

Pemeriksaan parasitemia dan kadar hemoglobin dilakukan setiap hari dengan menggunakan sampel darah dari ekor mencit. Pengukuran kadar parasitemia dilakukan berdasarkan ketentuan WHO (1991), yaitu dengan cara menghitung persen parasit di dalam 1.000 eritrosit (termasuk eritrosit yang terinfeksi parasit) pada sediaan hapusan darah tipis yang telah dicat dengan larutan Giemsa $5 \%$ dalam phosphate buffer saline (PBS).
Sedangkan pemeriksaan $\mathrm{Hb}$ dilakukan dengan metode sahli (Assistent, Germany) dengan satuan gr/dl (Depkes RI, 1991). Mencit pada kelompok kontrol dan kelompok perlakuan pada hari ketiga paska infeksi (kelompok H3) dan pada hari keenam paska infeksi (kelompok H6) dikorbankan dan diambil limpanya. Jaringan limpa yang diperoleh kemudian digunakan untuk isolasi RNA.

Ekspresi mRNA IL-10, TNF $\alpha$ dan IFN $\gamma$ dianalisis dengan tehnik RT-PCR (Reverse Transcription-Polymerase Chain Reaction), dengan tahap-tahap ekstraksi RNA untuk mendapatkan total RNA menggunakan reagen TRIZOL (Invitrogen Life Technologies, USA), dilanjutkan dengan penambahan oligoDT (AIT Biotech, Singapore) untuk mendapatkan mRNA dan proses Reverse Transcription menggunakan enzim MMLV (10.000 U cloned moloney murine leukemia virus (MMLV) reverse transcriptase enzyme) (Promega Corporation, Madison, USA) untuk mendapatkan cDNA, selanjutnya dilakukan PCR dengan sampel cDNA. Amplifikasi cDNA dilakukan dalam larutan PCR yang mengandung $10 \mathrm{mM}$ Tris$\mathrm{HCl}(\mathrm{pH} 8,6), 50 \mathrm{mM} \mathrm{KCl}, \mathrm{MgCl}_{2}$ pada konsentrasi akhir 1,5mM, dNTPs pada konsentrasi akhir 0,2 mM, 50 pmol setiap primer 2,5 U Taq DNA polymerase (Takara Ltd, Japan). Selanjutnya cDNA diamplifikasi dengan primer spesifik mencit (Genecraft Labs, German) sebagai berikut dalam tabel 1. DNA diamplifikasi menggunakan siklus denaturasi pada suhu $94^{\circ} \mathrm{C}$ selama 5 menit, 35 kali siklus annealing pada suhu $94^{\circ} \mathrm{C}$ selama 1 menit, $60^{\circ} \mathrm{C}$ selama 1 menit, $72^{\circ} \mathrm{C}$ selama 1 menit dan final extension pada suhi $72^{\circ} \mathrm{C}$ selama 20 menit. Pada RT-PCR ini, digunakan $\beta$-actin sebagai kontrol internal. Elektroforesis dilakukan pada $10 \mu \mathrm{l}$ DNA yang telah diamplifikasi dalam 1,5\% agarose-TAE yang mengandung ethidium bromide $0,5 \mu \mathrm{g} / \mathrm{ml}$. Selanjutnya ekspresi sitokin dari DNA yang telah diamplifikasi diidentifikasi dibawah sinar ultra violet (UV) (Iwaki, Japan) dan didokumentasi menggunakan kamera digital (Olympus Optical Co, Japan).

Data yang diperoleh selanjutnya dianalisis menggunakan student t-test dan korelasi Pearson dengan software SPSS. 
Tabel 1. Primer yang digunakan untuk RT-PCR

\begin{tabular}{|c|c|c|c|}
\hline \multicolumn{2}{|c|}{ Sitokin } & Nukleotida & Referensi \\
\hline TNF $\alpha$ & sense & $\begin{array}{l}\text { GAAGCATGATCCGCGACG } \\
\text { TGG }\end{array}$ & $\begin{array}{l}\text { Kita et al, } \\
2000\end{array}$ \\
\hline & antisen & GTAGACCTGCCCGGACTC & \\
\hline & se & CGCAA & \\
\hline \multirow[t]{3}{*}{ IL-10 } & sense & $\begin{array}{l}\text { TCAAACAAAGGACCAGCT } \\
\text { GGACAACATACTG }\end{array}$ & $\begin{array}{l}\text { Kita et al, } \\
2000\end{array}$ \\
\hline & antisen & CTGTCTAGGTCCTGGAGT & \\
\hline & se & CCAGCAGACTCAA & \\
\hline \multirow[t]{2}{*}{$\mathrm{IFN} \gamma$} & sense & ACTGCCACGGCACAGTCA & $\begin{array}{l}\text { Kita et al, } \\
2000\end{array}$ \\
\hline & $\begin{array}{l}\text { antisen } \\
\text { se }\end{array}$ & GCGACTCCTTTTCCGCTT & \\
\hline \multirow[t]{2}{*}{$\beta$-actin } & sense & $\begin{array}{l}\text { GTTACCAACTGGGACGAC } \\
\text { A }\end{array}$ & $\begin{array}{l}\text { Kita et al, } \\
2000\end{array}$ \\
\hline & $\begin{array}{l}\text { antisen } \\
\text { se }\end{array}$ & $\begin{array}{l}\text { TGGCCATCTCCTGCTCGA } \\
\text { A }\end{array}$ & \\
\hline
\end{tabular}

\section{HASIL DAN PEMBAHASAN}

Penelitian ini dilakukan dengan tahapan dan hasil sebagai berikut :

Mencit pada kelompok survival digunakan untuk melihat masa hidup mencit BALB/c yang diinfeksi P.yoelii 17XL. Didapatkan bahwa terdapat sampel yang homogen karena seluruh mencit kelompok survival mati pada hari ke-6, seperti dapat dilihat pada grafik 1 .

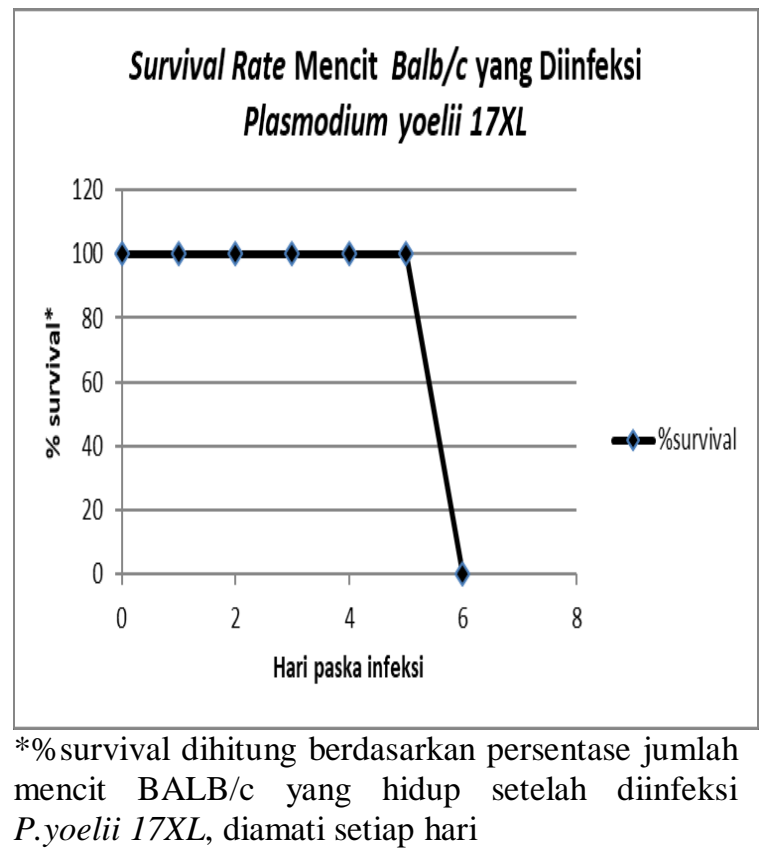

JBP Vol.20, No. 3, Desember 2018 - Sri Wijayanti Sulistyawati
Grafik 1. Masa Hidup Mencit BALB/c yang diinfeksi P.yoelii 17XL

Kadar hemoglobin mencit BALB/c yang diinfeksi $P$. yoelii $17 X L$ cenderung mengalami penurunan selama perlakuan, yaitu pada kelompok H3 dari $11 \mathrm{~g} / \mathrm{dl}$ saat sebelum infeksi menjadi 9,2 g/dl pada hari ke-2 paska infeksi, sedang pada kelompok H6 dari 10,7 g/dl menjadi 9,8 g/dl. Setelah hari ke-3 paska infeksi kadar hemoglobin mengalami penurunan yang semakin besar hingga pada kelompok H6 hari ke-6 paska infeksi mencapai kadar hemoglobin 4,9 mg/dl seperti dapat dilihat pada grafik 2 .

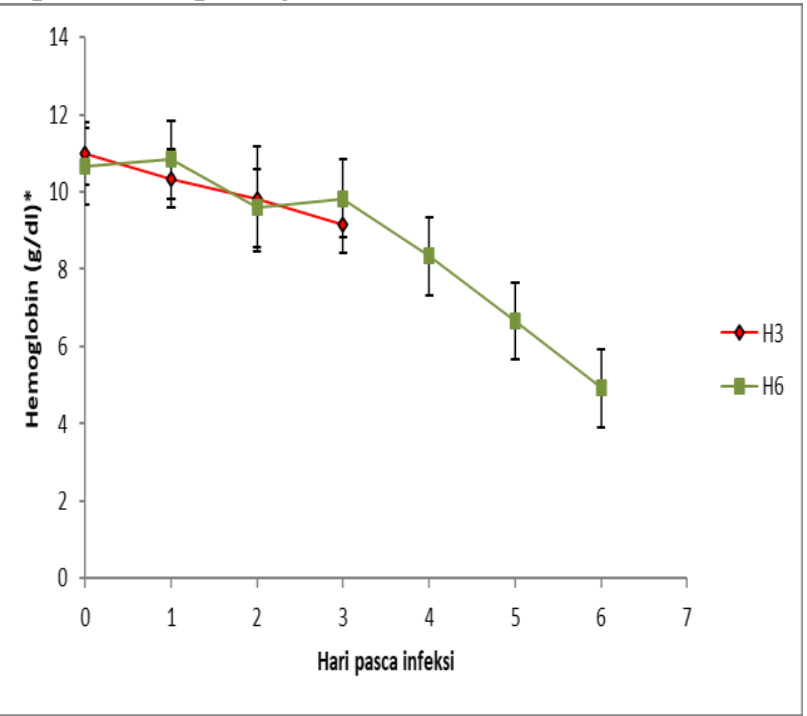

* Kadar hemoglobin diukur menggunakan metode Sahli (g/dl), sediaan darah diambil dari ujung ekor (mean $\pm \mathrm{SD}$ ). Jumlah mencit pada setiap kelompok : 6 ekor.

Grafik 2. Kadar Hemoglobin mencit BALB/c yang diinfeksi $P$. yoelii 17XL secara intraperitoneal.

Perbandingan $\mathrm{Hb}$ antara kelompok H0, H3, dan H6 menunjukkan perbedaan yang signifikan $(\mathrm{p}<0,05)$ (lihat tabel 2). Hal ini dibuktikan pula dengan perbedaan signifikan antara kelompok H0 dan H6 ( $<<0,05)$, serta kelompok H3 dan H6 ( $<<0,05)$, namun antara kelompok H0 dan H3 tidak signifikan (lihat tabel 2). Sehingga dapat dikatakan terjadi penurunan kadar hemoglobin, yang nyata terlihat setelah hari ke-3 paska infeksi. 
Parasitemia mencit BALB/c yang diinfeksi $P$. yoelii $17 X L$ diperiksa setiap hari setelah infeksi. Hasil pemeriksaan menunjukkan parasitemia dapat dideteksi mulai hari pertama setelah injeksi, meskipun parasitemia yang terjadi pada hari pertama hingga kedua paska infeksi relatif rendah, yaitu pada kelompok $\mathrm{H} 3$ sebesar $0,33 \%$ (hari ke-1) dan 0,36\% (hari ke-2), pada kelompok H6 sebesar $0,26 \%$ (hari ke-1) dan 1,04\% (hari ke-2). Parasitemia mulai paten pada hari ketiga setelah infeksi, dan terus meningkat dengan cepat hingga mencapai $66,16 \%$ pada kelompok H6 di hari keenam paska infeksi (lihat grafik 3).

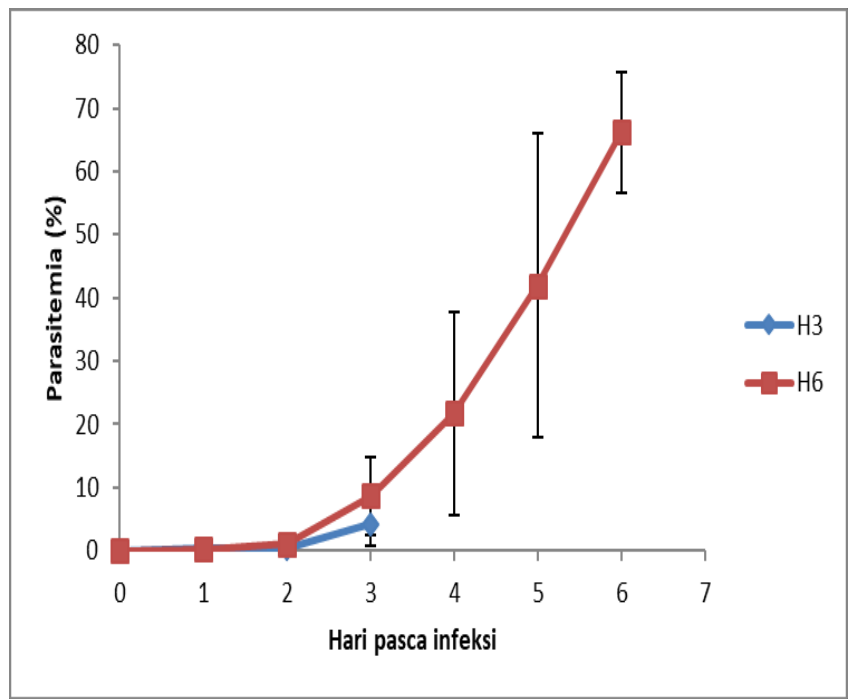

Grafik 3. Parasitemia* mencit BALB/c yang diinfeksi $10^{5} P$. yoelii $17 \mathrm{XL}$ secara intraperitoneal.

*Parasitemia dihitung berdasarkan persentase jumlah eritrosit terinfeksi dalam 1.000 eritrosit normal yang diperiksa dari sediaan hapusan darah yang dicat Giemsa dan diperiksa dibawah mikroskop cahaya dengan pembesaran $1.000 \mathrm{x}$ (mean $\pm \mathrm{SD})$.

H3: Kelompok yang dikorbankan pada hari ke-3, H6: Kelompok yang dikorbankan pada hari ke-6, Jumlah mencit pada setiap kelompok : 6 ekor.

Analisis statistik menunjukkan adanya peningkatan parasitemia yang signifikan pada H6 bila dibandingkan dengan $\mathrm{H} 3 \quad(\mathrm{p}<0,05)$ (lihat tabel 2).
Tabel 2. Perbandingan kadar hemoglobin antara kelompok H0, H3 dan H6 pada Mencit BALB/c yang diinfeksi $P$. yoelii $17 X L$

\begin{tabular}{|c|c|c|c|c|}
\hline \multirow[t]{2}{*}{ Variabel } & \multicolumn{3}{|c|}{ Kelompok* $^{*}$} & \multirow[b]{2}{*}{ harga $p$} \\
\hline & $\mathrm{HO}$ & $\mathrm{H} 3$ & H6 & \\
\hline $\begin{array}{c}\text { Kadar } \\
\text { Hemoglobin } \\
(\mathrm{g} / \mathrm{dl})\end{array}$ & $10.67 \pm 0.82^{\mathrm{a}}$ & $9.2 \pm 1.17^{\mathrm{a}}$ & $4.9 \pm 1.8^{\mathrm{b}}$ & $<0.0001$ \\
\hline $\begin{array}{c}\text { Parasitemia } \\
(\% \text { iRBC } \\
\text { per } 1000 \\
\text { eritrosit } \\
\text { normal) }\end{array}$ & - & $4.2 \pm 3.3^{c}$ & $66.16 \pm 9.45^{\mathrm{d}}$ & 0.031 \\
\hline
\end{tabular}

Notasi huruf a dan $\mathrm{b}$ dalam satu baris adalah berbeda secara signifikan $(\mathrm{p}<0,05)$. Notasi huruf $\mathrm{c}$ dan $\mathrm{d}$ dalam satu baris adalah berbeda secara signifikan $(\mathrm{p}<0,05)$

Tabel 3. Tabel korelasi antara variabelvariabel pada Mencit $\mathrm{BALB} / \mathrm{c}$ yang diinfeksi

\begin{tabular}{lll}
$P$. & yoelii & $17 X L$ \\
\hline & $\begin{array}{l}\text { Parasitemia } \\
(\% \quad \text { iRBC } \\
\text { per } 1000 \\
\text { eritrosit } \\
\text { normal })\end{array}$ & $\begin{array}{l}\text { Kadar } \\
\text { Hemoglobin } \\
(\mathrm{g} / \mathrm{dl})\end{array}$ \\
$\begin{array}{lll}\text { Parasitemia }(\% \\
\text { iRBC per 1000 } \\
\text { eritrosit } \\
\text { normal) }\end{array}$ & - & $\mathrm{r}=-0.898$ \\
\hline $\begin{array}{l}\text { Kadar } \\
\text { Hemoglobin } \\
(\mathrm{g} / \mathrm{dl})\end{array}$ & $\mathrm{p}<0.0001$ \\
\hline
\end{tabular}

Hubungan antara parasitemia dengan $\mathrm{Hb}$ menunjukkan korelasi yang signifikan $(\mathrm{p}<0,01)$ (lihat tabel 3). Hal ini menunjukkan terjadi peningkatan parasitemia yang nyata terlihat setelah hari ke-3 paska infeksi, sejalan dengan penurunan kadar hemoglobin.

Hasil RT-PCR pada limpa mencit BALB/c yang diinfeksi $P$. yoelii $17 \quad X L$ menunjukkan mRNA IL-10 pada H0 (sebelum diinfeksi) tidak terekspresi, begitu pula dengan IFN $\gamma$ dan TNF $\alpha$ pada H0 (sebelum diinfeksi) tidak terekspresi, sedangkan pada $\mathrm{H} 3$ (hari ke3 paska infeksi) terlihat ekspresi mRNA IL10, IFN $\gamma$ dan TNF $\alpha$. Pada H6 (hari ke-6 paska infeksi) mRNA IL-10, IFN $\gamma$ dan TNF $\alpha$, kembali tidak terekspresi (lihat gambar 1). 


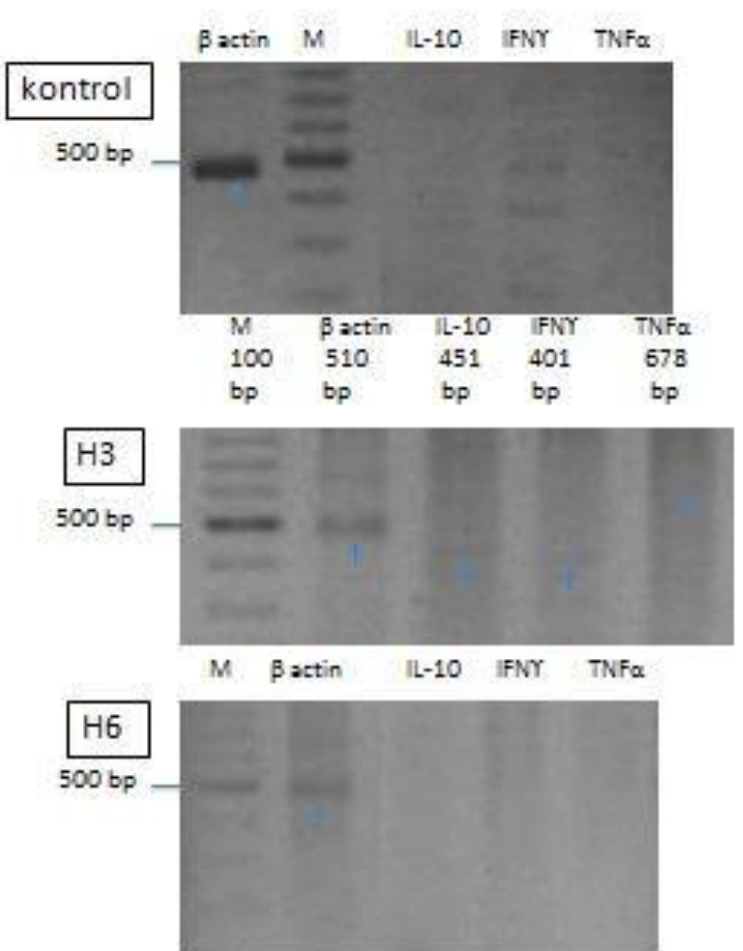

Gambar 1. Hasil pemeriksaan RTPCR limpa mencit BALB/c yang diinfeksi $P$. yoelii 17XL.

Ket :H0 ; kontrol negatif, H3: kelompok yang dikorbankan pada hari ke-3 paska infeksi $1 \times 10^{5} P$. yoelii 17XL, H6: kelompok yang dikorbankan pada hari ke-6 paska infeksi $1 \times 10^{5}$ P. yoelii $17 X L$; RT-: sampel yang tidak diberi enzim MMLV;M: marker (penanda);RT+: kontrol internal (menggunakan $\beta$-actin)

Pemahaman mekanisme malaria berat sangat tergantung pada penelitian dengan model malaria pada mencit (Zhu et al, 2012).

P. yoelii $17 X L$ merupakan parasit yang dapat menyebabkan anemia berat (Weissberg et al, 2012; Fu et al, 2012; Zhu dll,2012; Totino et al, 2010; Langhorne, 2005) dan bersifat letal (Kobayashi et al, 1996;Couper et al, 2008;Jaular et al, 2011)

Manifestasi yang didapat pada penelitian ini sejalan dengan hasil penelitian lain yang serupa, yaitu adanya anemia ( $\mathrm{Fu}$ et al, 2012; Totino et al, 2010), hiperparasitemia (Fahey and Spitalny, 1984; Zhu et al, 2012; Fu et al, 2012; Totino et al, 2010; Sanni et al, 2002; Langhorne, 2002; Scholzen, 2009). Hal ini menjelaskan bahwa model infeksi malaria P. yoelii $17 X L$ pada mencit $\mathrm{BALB} / \mathrm{c}$ ini dapat digunakan sebagai hewan coba untuk mempelajari imunopatogenesis malaria (Waisberg et al, 2012; Fu et al, 2012;Zhu dll,2012; Jaular et al, 2011; Totino et al, 2010; Couper et al, 2008;Langhorne, 2005). Malaria berat pada model hewan coba ini terjadi pada hari ke-4 paska infeksi apabila dilihat dari tingkat parasitemia, sedangkan apabila didasarkan tingkat anemia, malaria berat terjadi pada hari ke-6 paska infeksi.

Penelitian ini menjelaskan patogenesis malaria berat dan letalitas yang terjadi, dengan manifestasi utama pada anemia berat dan hiperparasitemia, sesuai dengan kriteria WHO tahun 2010.

Ciri khas yang membedakan infeksi $P$. yoelii strain letal dan nonletal adalah kemampuan $P$. yoelii strain letal untuk menginvasi eritrosit matur, produksi dini sitokin antiinflamatori, dan aktivasi Treg CD4+CD25+ (Fu et al, 2012).

Hasil analisis RT-PCR menunjukkan ekspresi mRNA IL-10, TNF- $\alpha$, dan IFN- $\gamma$ yang meningkat pada $\mathrm{H} 3$, sedangkan pada $\mathrm{HO}$ dan pada H6 tidak terekspresi. Hal ini berbeda dengan beberapa penelitian sebelumnya yang menyatakan peningkatan kadar IL-10 yang terus meningkat pada minggu pertama selama infeksi malaria mencit (Couper et al, 2008;Kobayashi et al, 1996; Shibui et al, 2009). Berbeda pula dengan penelitian yang dilakukan oleh Millington et al (2006), yaitu dengan eksperimen malaria in vivo dan in vitro, mendapatkan hasil kadar sitokin IL-10, IL-12, dan IL-2, IFN $\gamma$ yang sangat rendah sejak hari pertama infeksi.

Perbedaan hasil yang didapat pada penelitian ini kemungkinan karena penelitian ini menggunakan RT-PCR untuk mengukur kadar mRNA, sedangkan penelitian Couper et al, 2008; Kobayashi et al, 1996; Shibui et al, 2009, dilakukan dengan menggunakan ELISA untuk mengukur kadar protein. Perbedaan kadar mRNA dan protein, dapat disebabkan ekspresi protein yang sangat rendah, sensitifitas teknik, proses sampel, dan perbedaan area transkripsi dengan protein yang dihasilkan (Pascal et al, 2008).

Pada penelitian ini diperkirakan terjadi produksi dini IL-10 pada awal infeksi dan imunosupresi pada akhir infeksi. 
Interpretasi pada fase awal (hari ke-3 paska infeksi) sejalan dengan Hassan et al, yang menyatakan bahwa produksi IL-10 dengan konsentrasi tinggi pada fase awal yang paralel dengan produksi TNF $\alpha$ yang persisten dan nyata akan merubah keadaan dari infeksi ringan menjadi bentuk yang berat. Hal ini didasarkan pada fakta bahwa produksi pada fase awal dari IL-10 menghambat pelepasan IL-12 dan konsekuensinya menghambat pula IFN $\gamma$ yang dibutuhkan untuk klirens parasit malaria. Selain itu, sekresi persisten TNF $\alpha$ disertai dengan penurunan produksi IL-10 dan TGF- $\beta$ selama fase transisi dari respon imun innate menuju respon imun adaptif juga akan menyebabkan progresifisitas ke arah malaria berat.

Interpretasi pada hari ke-6 paska infeksi (late infection) yaitu tidak didapatkan ekspresi IL-10, TNF $\alpha$, dan IFN $\gamma$, sejalan dengan penelitian Millington et al (2006).

Pada penelitian ini didapatkan ekspresi IL-10, TNF $\alpha$, dan IFN $\gamma$ pada awal infeksi namun tidak didapatkan ekspresi IL-10 dan sitokin-sitokin lain pada akhir infeksi, sehingga diperkirakan letalitas dan hiperparasitemia yang terjadi disebabkan proses inflamasi pada awal infeksi dan imunosupresi pada akhir infeksi.

Letalitas parasit $P$. yoelii $17 X L$ terjadi karena parasitemia meningkat persisten, tidak terdapat respon Th1 yang efektif yang ditandai dengan produksi dini IFN $\gamma$. Hal ini sesuai dengan Zhu et al (2012).

Hiperparasitemia yang tinggi menunjukkan kontrol parasit yang tidak efektif, yang seharusnya diperankan oleh IFN $\gamma$, IL-12, dan IL-18, hal ini sesuai dengan Wroczynska (2005).

Hasil penelitian ini sejalan dengan penelitian pada anak-anak di Ghana yang terkena malaria falsiparum, kadar IL-10 dalam sirkulasi yang rendah berhubungan dengan anemia malaria yang berat (Wilson et al, 2005). Namun, kadar IL-10 dan TNF $\alpha$ yang tinggi juga dilaporkan pada kasus malaria berat dan dengan komplikasi serta pada malaria anak dengan parasitemia yang tinggi (Othoro et al,1999; Keller et al, 2006). Rasio IL-10 terhadap TNF yang tinggi dilaporkan pada pasien malaria falsiparum pada daerah endemis dengan malaria tanpa komplikasi atau hiperparasitemia (Trinchieri, 2001). Masih terdapat hasil yang kontradiktif mengenai IL-10 pada infeksi malaria di manusia.

Pada penelitian ini, tidak didapatkan hasil yang persis sama dengan yang terjadi pada manusia. Perjalanan dan keparahan penyakit tergantung pada usia, konstitusi genetik, imunitas spesifik malaria, status nutrisi, dan paparan terhadap obat antimalaria (Crawley et al, 2010). Hal ini tidak terjadi pada model hewan coba mencit, yang merupakan keterbatasan hewan coba, sehingga gambaran perjalanan klinisnya tidak persis dengan pada manusia.

\section{KESIMPULAN DAN SARAN}

Terdapat ekspresi mRNA IL-10, $\mathrm{TNF} \alpha$ dan IFN $\gamma$ pada model mencit BALB/c yang diinfeksi $P$. yoelii $17 X L$ pada hari ke-3 paska infeksi dibandingkan kontrol. Hal ini disertai dengan peningkatan parasitemia yang sejalan dengan penurunan kadar hemoglobin, nyata terlihat setelah hari ke-3 paska infeksi,

Namun pada hari ke-6 paska infeksi $P$ yoelii $17 X L$ pada mencit $\mathrm{BALB} / \mathrm{c}$ tidak didapatkan ekspresi mRNA IL-10, TNF $\alpha$ dan IFN $\gamma$. Tidak adanya ekspresi mRNA IL-10 pada hari ke-6 paska infeksi menunjukkan kemungkinan adanya kegagalan regulator respon imun dalam infeksi malaria berat. Diperkirakan letalitas dan hiperparasitemia yang terjadi disebabkan proses inflamasi pada awal infeksi dan imunosupresi pada akhir infeksi.

Penelitian lanjut kadar dan ekpresi protein IL-10 sangat diperlukan dengan interval waktu pemeriksaan yang lebih sempit, maupun dengan menggunakan metode lain seperti ELISA, Real Time PCR, atau imunohistokimia, untuk menjelaskan aspek molekular pada respon imun terhadap $P$. yoelii $17 X L$. Juga diperlukan pemeriksaan komponen imun lain yang dapat menggambarkan kondisi imunosupresi dan memperjelas patogenesis malaria misalnya GM-CSF, hitung eritrosit, hitung monosit, hitung retikulosit, dan lain-lain 


\section{UCAPAN TERIMA KASIH}

Terima kasih kami ucapkan kepada Bu Rita Marletta dan Bpk Ondri Dwi Sampurno dari BALITBANGKES atas pemberian isolat $P$. yoelii, Haruki Uemura, PhD dari Department of Protozoology, Institute of Tropical Medicine, Nagasaki University, atas bantuan sebagian besar alat dan bahan penelitian, dan segenap staf LPT UNAIR yang telah membantu pemeliharaan hewan coba dan seluruh staf Kelompok Studi Malaria yang telah membantu memperlancar penelitian.

\section{DAFTAR PUSTAKA}

Angulo I and Fresno M, 2002. Cytokines in the Pathogenesis of and Protection against Malaria.Clin.Diagn. Lab. Immunol. 9(6):1145-1152.

Couper KN et al, 2008. IL-10 from CD4+CD252Foxp32CD1272

Adaptive Regulatory $\mathrm{T}$ Cells Modulates Parasite Clearance and Pathology during Malaria Infection. PLoS Pathog 4(2): e1000004

Crawley J, Chu C, Nosten F. Malaria in children Lancet 2010; 375: 1468-81

Depkes RI : Petunjuk Pemeriksaan Laboratorium Puskesmas, 1991. Jakarta: Departemen Kesehatan RI

Fahey JR and Spitalny, 1984.Virulent and Nonvirulent Forms of Plasmodium yoelii Are Not Restricted to Growth Within a Single Erythrocyte Type. Infection and Immunity 44(1):151156

Freitas do Rosario AP and Langhorne J, 2012. $\mathrm{T}$ cell-derived IL-10 and its impact in the regulation of host responses during malaria. International Journal for Parasitology

Fu Y, Ding Y, Zhou T, et al,2012. Comparative Histopathology of Mice Infected With the 17XL and 17XNL Strains of Plasmodium yoelii. Journal of Parasitology, 98(2):310-315

Hassan et al,2011.Cytokines and their role in modulating the severity of Plasmodium falciparum malaria.
Khartoum Medical Journal 3 (1) :373-376

Jaular LM et al, 2011. Strain-spesific spleen remodelling in Plasmodium yoelii infections in Balb/c mice facilitates adherence and spleen macrophage-clearance escape. Cellular Microbiology 13(1):109122

Keller CC et al, 2006. Acquisition of Hemozoin by Monocytes DownRegulates Interleukin-12p40 (IL12p40) Transcripts and Circulating IL-12p70 through an IL-10-Dependent Mechanism: In Vivo and In Vitro Findings in Severe Malarial Anemia. Infection and Immunity 74(9):5249-5260

Kita M, Tong L, Tanaka K, Imanishi J, 1992. Expression de l'ARNmessager des cytokines chez la Souris dans des condition physiologiques. Int Immunol 4 (4): 475-485

Kobayashi F, Morii T, Matsui T, et al, 1996. Production of interleukin 10 during malaria caused by lethal and nonlethal variants of Plasmodium yoelii yoelii Parasitol Res (1996) 82:385-391

Langhorne $\mathbf{J}$ et al,2008. Immunity to malaria: more questions than answers. Nature immunology 9 (7) : 725-732

Langhorne J, Quin SJ, andSanni LA, 2002. Mouse models of bloodstage malaria infections: immune responses and cytokines involved in protection and pathology. Dalam (Perlmann PT andBlomberg $\mathrm{M}$, eds). Malaria Immunology, Chem. Immunol. Basel :Karger 80:204-228

Long $\mathrm{G} \quad \mathrm{H}$ et al,2008. Experimental manipulation of immune-mediated disease and its fitness costs for rodent malaria parasites. $B M C$ Evolutionary Biology 8:128

Millington OR, Di Lorenzo C, Phillips R.S, Garside P, and Brewer J.M, 2006. Suppression of adaptive 
immunity to heterologous antigens during Plasmodium infection through hemozoininduced failure of dendritic cell function. $J$ Biol 5: 5.

Niikura M, Inoue S, Kobayashi F, 2010. Role of Interleukin-10 in Malaria: Focusing on Coinfection with Lethal and Nonlethal Murine Malaria Parasite. Journal of Biomedicine and Biotechnology:18

Othoro C et al, 1999.A Low Interleukin10 Tumor Necrosis Factor-a Ratio Is Associated with Malaria Anemia in Children Residing in a Holoendemic Malaria Region in Western Kenya. The Journal of Infectious Diseases 179:279-82

Pascal LE, True LD, Campbell DS, et al, 2008. Correlation of mRNA and protein levels: Cell type-specific gene expression of cluster designation antigens in the prostate. BMC Genomics $9: 246$

Penman B and Gupta S, 2008. Evolution of virulence in malaria. Journal of Biology 7:22

Riley EM et al, 2006. Regulating immunity to malaria. Parasite Immunology 28:35-49

Sanni LA, Fonseca LF, Langhorne J, 2002. Mouse models of erythrocytic-stage malaria Dalam (Doolan DL, eds). Malaria Methods and Protocols. Humana Press 72: 57-62

Schofield L and Grau GE. 2005. Immunological Processes in Malaria Pathogenesis.Immunology.Nature Publishing Group5 :722-735

Scholzen A, Minigo G, Plebanski M, 2009. Heroes or villains? T regulatory cellsin malaria infection. Trends in Parasitology 26(1): 16-25

Shibui A et al, 2009. CD4+ T cell response in early erythrocytic stage malaria: Plasmodium berghei infection in $\mathrm{BALB} / \mathrm{c}$ and
C57BL/6 mice. Parasitol Res 105:281-286.

Totino P RR, Magalhaes AD, Silva LA, et al,. 2010, Apoptosis of nonparasitized red blood cells in malaria: a putative mechanism involved in the pathogenesis of anaemia. Malaria Journal 9:350

Trinchieri G, 2001. Regulatory Role of T Cells Producing both Interferon $\gamma$ and Interleukin 10 in Persistent Infection. J. Exp. Med 194(10) : F53-F57

Waisberg M, Vickers BK, Yager SB, et al, 2012.Testing in Mice the Hypothesis That Melanin Is Protective in Malaria Infections. PlosOne 7(1): e29493

WHO, 1991. Basic Malaria Microscopy Part I. Learner's Guide. Geneva, Switzerland

WHO, 2010, Guidelines for the treatment of Malaria, 2nd ed, Geneva, Switzerland

WHO, 2010, World Malaria Report, Geneva, Switzerland

WHO-SEARO, 2011. Malaria Situation, Geneva, Switzerland

Wilson JN et al, 2005.Analysis of IL10 haplotypic associations with severe malaria. Genes and Immunity 6: 462-466

Wroczynska A, Nahorski W, Bakowska A, et al, 2005. Cytokines and ClinicalManifestations of Malaria in Adults with Severe and Uncomplicated Disease. Internat. Marit. Health 56: 1 - 4

Zainuddin A, 2000. Metode Penelitian. Program Pasca SarjanaUnair, Surabaya, hlm 73-74

Zhu X, Pan Y, Zheng L, et al, 2012, Polysaccharides from the Chinese medicinal herb Achyranthes bidentata enhance anti-malarial immunity during Plasmodium yoelii 17XL infection in mice. Malaria Journal 11:49 